\title{
Internal Controls For The Income Producing Real Estate Industry
}

\author{
Tim Kizirian, Ph.D., CPA, California State University, Chico, USA \\ Tim Heinze, Ph.D., California State University, Chico, USA \\ Wallace Leese, Ph.D., CMA, California State University, Chico, USA \\ Samir Nissan, Ph.D., CPA, California State University, Chico, USA \\ Paule Pobloske, MBA, CPA, California State University, Chico, USA
}

\begin{abstract}
The current paper focuses on internal controls in the income producing real estate industry. The industry is unique in that most revenue is generated from contractual lease agreements. Since the revenue cycle is a principal area of waste, fraud and abuse, revenue-related internal controls are critical. An industry-specific list of controls is presented and can be used by accounting professionals and managers of income producing real estate firms to benchmark the appropriateness and sufficiency of their own internal controls. The paper can also be used in training settings to demonstrate the manner in which internal controls are often industry-specific.
\end{abstract}

Keywords: Internal Control; Control Objectives; Control Procedures; Income Producing Real Estate

\section{INTRODUCTION}

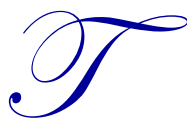

he recent downturn in the real estate industry, coupled with today's difficult economic climate, requires business managers to carefully consider all aspects of business operations to minimize waste and increase efficiency. ${ }^{1}$ The revenue cycle continues to be the primary area of waste, fraud and abuse requiring a comprehensive system of internal controls (AICPA, 2002). Similar to Kizirian et al. (2011), this paper focuses on the high risk area of revenues. Internal controls assist management in producing accurate and reliable information, adhering to management's policies and procedures, and safeguarding assets. ${ }^{2}$ Therefore, internal controls in the revenue cycle are of critical importance. The current paper provides a control review checklist for the revenue cycle of the income producing real estate industry. Extant studies on internal controls are typically more generic in nature and neglect the predominant characteristic of revenue generated from lease agreements. This unique characteristic distinguishes the income producing real estate industry.

The paper's checklist can be used as a general benchmark for management's preliminary evaluations of a company's internal control system in the income producing real estate industry. Auditors can compare their client's control objectives to the presented objectives. During preliminary investigations of the company's internal control system, auditors may review whether key control objectives have been omitted and whether the omission invites heightened risk. The checklist provides management with a review of internal controls that external, independent auditors consider significant.

\section{A REVENUE CYCLE REVIEW CHECKLIST FOR INCOME PRODUCING REAL ESTATE FIRMS}

Tables 1 and 2 present a checklist of control objectives and activities that should be referenced when conducting a preliminary audit of real estate industry revenue. Table 1 lists significant revenue cycle control

\footnotetext{
${ }^{1}$ A monthly national index for all properties set at 1.0 for the year 2000 peaked in October 2007 at 1.91118 . In March 2011 the index was 1.017119 (Moody's 2011).

${ }^{2}$ Companies use internal controls as checks on a variety of processes, including financial reporting, operating efficiency and effectiveness, and compliance with applicable laws and regulations (PCAOB, 2007).
}

(C) 2012 The Clute Institute http://www.cluteinstitute.com/ 
objectives. The objectives are followed by alpha numeric characters that reference the control activities listed in Table 2. The numeric portion of the reference explicitly refers to the control activities (listed numerically in Table 2 ), and the alpha portion ("F" or "P") indicates whether or not the referenced activity "fully" or "partially" meets the given objective's requirements.

Table 1

Control Objectives and Suggested Control Activities

\begin{tabular}{|c|c|}
\hline \multirow{2}{*}{ Control Objectives } & \multirow{2}{*}{ Control Activities Listed in Table 2} \\
\hline & \\
\hline $\begin{array}{l}\text { Leases are not executed if the tenant's credit worthiness does not meet } \\
\text { management's established standards. }\end{array}$ & $13 \mathrm{P}, 15 \mathrm{~F}, 37 \mathrm{~F}$ \\
\hline Lease and lease amendments are approved by management prior to execution. & $16 \mathrm{~F}, 22 \mathrm{~F}, 32 \mathrm{P}, 34 \mathrm{P}$ \\
\hline All leases and lease amendments are documented and filed. & $20 \mathrm{~F}, 41 \mathrm{P}, 45 \mathrm{P}$ \\
\hline Invoices are accurately calculated and recorded. & $5 \mathrm{P}, 19 \mathrm{P}, 29 \mathrm{~F}, 35 \mathrm{P}, 38 \mathrm{P}$ \\
\hline Adjustments to accounts receivable are accurately calculated and recorded. & $5 \mathrm{P}, 7 \mathrm{~F}, 9 \mathrm{P}, 36 \mathrm{P}$ \\
\hline Invoices relate to valid lease agreements. & $4 \mathrm{~F}, 12 \mathrm{P}, 42 \mathrm{P}, 43 \mathrm{P}$ \\
\hline All invoices issued are recorded. & $3 \mathrm{P}, 21 \mathrm{~F}, 45 \mathrm{P}$ \\
\hline Invoices are recorded in the appropriate period. & $3 \mathrm{P}, 23 \mathrm{P}$ \\
\hline $\begin{array}{l}\text { Accounts Receivables reflect the existing business circumstances and economic } \\
\text { conditions in accordance with the accounting policies being used. }\end{array}$ & $8 \mathrm{~F}$ \\
\hline Cash receipts are recorded in the period in which they are received. & 10F, 24F, 28P \\
\hline Cash receipts data is entered for processing accurately. & $12 \mathrm{P}, 24 \mathrm{P}, 25 \mathrm{P}, 26 \mathrm{P}, 27 \mathrm{~F}, 28 \mathrm{P}, 30 \mathrm{P}, 31 \mathrm{P}$ \\
\hline All cash receipts data is entered for processing. & $12 \mathrm{P}, 24 \mathrm{P}, 26 \mathrm{P}, 27 \mathrm{~F}, 28 \mathrm{P}, 30 \mathrm{P}, 31 \mathrm{P}$ \\
\hline Cash receipts data is valid and is entered for processing only once. & 24P, 27P, 28P, 34P \\
\hline Timely collection of accounts receivable is monitored. & $1 \mathrm{P}, 2 \mathrm{~F}, 30 \mathrm{~F}, 40 \mathrm{~F}$ \\
\hline Only valid changes are made to property rent rolls. & $6 \mathrm{P}, 11 \mathrm{~F}, 14 \mathrm{P}, 17 \mathrm{P}, 18 \mathrm{~F}, 39 \mathrm{~F}, 46 \mathrm{P}$ \\
\hline $\begin{array}{l}\text { All valid changes to tenant lease files are input and appropriately processed in } \\
\text { property rent rolls. }\end{array}$ & $14 \mathrm{P}, 17 \mathrm{P}, 18 \mathrm{~F}, 39 \mathrm{~F}$ \\
\hline Changes to tenant lease files are accurately input in property rent rolls. & $11 \mathrm{~F}, 14 \mathrm{P}, 17 \mathrm{P}, 18 \mathrm{~F}, 33 \mathrm{P}, 39 \mathrm{~F}, 46 \mathrm{P}$ \\
\hline Changes to tenant lease files and property rent rolls are processed timely. & $14 \mathrm{P}, 17 \mathrm{P}, 18 \mathrm{~F}, 39 \mathrm{~F}$ \\
\hline $\begin{array}{l}\text { Tenant lease files and property rent rolls remain relevant to the current business } \\
\text { environment. }\end{array}$ & $14 \mathrm{P}, 17 \mathrm{P}, 18 \mathrm{~F}, 39 \mathrm{P}$ \\
\hline $\begin{array}{l}\text { Lease data is transferred completely and accurately to the system which generates } \\
\text { the property rent roll, accounts receivable aging and general ledger postings. }\end{array}$ & $19 \mathrm{~F}$ \\
\hline
\end{tabular}

Table 2

Suggested Control Activities

\begin{tabular}{|c|l|}
\hline $\begin{array}{c}\text { Numerical } \\
\text { Values }\end{array}$ & \multicolumn{1}{c|}{ Control Activities } \\
\hline 1 & Accounts receivable aging reports are prepared regularly and analyzed. \\
\hline 2 & Collection procedures established by management for overdue accounts are performed as intended. \\
\hline 3 & $\begin{array}{l}\text { Recorded rental revenue, tenant reimbursement revenue, and other income are compared to budgeted values } \\
\text { regularly; management reviews and approves significant variances. }\end{array}$ \\
\hline 4 & $\begin{array}{l}\text { Data input to the invoicing component of the information system is compared to source documents or system } \\
\text { reports generated from source documents; differences require management approval before invoices can be } \\
\text { processed. }\end{array}$ \\
\hline 5 & Invoices are edited and validated; identified errors are corrected immediately. \\
\hline 6 & $\begin{array}{l}\text { Significant changes to tenant leases and property rent rolls are approved by management. Management clearly } \\
\text { defines a material or significant change. }\end{array}$ \\
\hline 7 & Management approves bad-debt write-offs and other adjustments to accounts receivable. \\
\hline 8 & Management reviews and approves the allowance for doubtful accounts receivable. \\
\hline 9 & $\begin{array}{l}\text { Management monitors the nature, volume, and amounts of recorded write-offs and other adjustments to accounts } \\
\text { receivable. }\end{array}$ \\
\hline 10 & $\begin{array}{l}\text { Cash receipts are periodically scrutinized and/or reconciled to ensure complete and consistent recording in the } \\
\text { appropriate accounting period. }\end{array}$ \\
\hline 11 & $\begin{array}{l}\text { Recorded changes to property rent rolls are compared to tenant leases to ensure that data was entered into the } \\
\text { system accurately. }\end{array}$ \\
\hline 12 & Accounts receivable statements are mailed periodically to tenants. \\
\hline
\end{tabular}




\begin{tabular}{|c|c|}
\hline 13 & rospective tenants' financial position and creditworthiness are obtained and reviewed prior to lease execution. \\
\hline 14 & $\begin{array}{l}\text { Property rent rolls are periodically compared to tenant leases by management for accuracy and ongoing } \\
\text { appropriateness. }\end{array}$ \\
\hline 15 & Leases are only signed subsequent to review of prospective tenant's credit worthiness. \\
\hline 16 & Leases and lease amendments are approved by management prior to execution. \\
\hline 17 & Lease entry and lease termination data is edited and validated; identified errors are corrected promptly. \\
\hline 18 & $\begin{array}{l}\text { Recorded lease initiation and lease termination data is compared to source documents by an individual who is } \\
\text { independent of the lease entry process. }\end{array}$ \\
\hline 19 & $\begin{array}{l}\text { Data in the property rent roll is compared to lease agreements for accuracy; identified errors are corrected } \\
\text { promptly. }\end{array}$ \\
\hline 20 & $\begin{array}{l}\text { Property rent rolls and tenant lease files are periodically compared to tenant spaces by an individual independent of } \\
\text { the lease signing process. }\end{array}$ \\
\hline 21 & $\begin{array}{l}\text { Invoices are sequentially pre-numbered. The sequence of invoices processed is accounted for. "PPN" - preprinted, } \\
\text { pre-numbered, numerically sequenced. }\end{array}$ \\
\hline 22 & Significant or unusual lease agreements are specifically approved by management as to rates and terms. \\
\hline 23 & $\begin{array}{l}\text { Data input to the property rent roll is compared to lease agreements for accuracy on a timely basis; identified errors } \\
\text { are corrected promptly. }\end{array}$ \\
\hline 24 & Bank statements are reconciled to the general ledger regularly. \\
\hline 25 & Cash receipts input data is edited and validated; identified errors are corrected promptly. \\
\hline 26 & $\begin{array}{l}\text { Cash receipts transactions are batched and batch input data is balanced; out-of-balance batches are corrected } \\
\text { promptly. }\end{array}$ \\
\hline 27 & $\begin{array}{l}\text { Tenants are provided with a form acknowledging receipt of any cash payments (i.e., a cash receipt form) and cash } \\
\text { receipts forms are balanced to cash deposited to the bank. Cash receipt forms are sequentially pre-numbered and } \\
\text { the sequence of such forms is accounted for. (PPN). }\end{array}$ \\
\hline 28 & $\begin{array}{l}\text { General ledger balances are reconciled to the accounts receivable subsidiary ledger and differences are resolved in } \\
\text { a timely manner. }\end{array}$ \\
\hline 29 & $\begin{array}{l}\text { Invoiced amounts, including tenant recoveries of common costs and contingent rent, are independently } \\
\text { recalculated. }\end{array}$ \\
\hline 30 & The accounting information system tenant open items report is prepared and analyzed regularly. \\
\hline 31 & The accounting information system does not allow processing of cash receipts outside of approved bank accounts. \\
\hline 32 & $\begin{array}{l}\text { The accounting information system restricts to authorized personnel the ability to create, change, or delete lease } \\
\text { agreements, and any other contracts or agreements. }\end{array}$ \\
\hline 33 & The accounting information system edits and validates changes to property rent records in real time. \\
\hline 34 & $\begin{array}{l}\text { The accounting information system restricts to authorized personnel the ability to modify the lease pricing } \\
\text { information. }\end{array}$ \\
\hline 35 & The accounting information system automatically calculates invoices based on system configuration data. \\
\hline 36 & $\begin{array}{l}\text { The accounting information system restricts to authorized personnel the ability to create, change, or delete "sales } \\
\text { order returns" (from lease changes) and credit note requests and subsequent credit note transactions. }\end{array}$ \\
\hline 37 & The accounting information system does not allow processing of lease agreements that exceed tenant credit limits. \\
\hline 38 & $\begin{array}{l}\text { The accounting information system posts invoices to general ledger accounts based on rent invoice configuration } \\
\text { data. }\end{array}$ \\
\hline 39 & $\begin{array}{l}\text { The accounting information system reports changes to tenant master data and tenant credit information are } \\
\text { compared to authorized source documents and/or a manual log of requested changes to ensure they were input } \\
\text { accurately and timely. }\end{array}$ \\
\hline 40 & The accounting information system accounts receivable aging reports are prepared regularly and analyzed. \\
\hline 41 & The accounting information system regularly produces rent reports that management analyzes. \\
\hline 42 & $\begin{array}{l}\text { The accounting information system triggers an open order to produce a lease for leases initiated. Management } \\
\text { closes each open order in a timely manner, thereby preventing further lease production for the same lease } \\
\text { agreement. }\end{array}$ \\
\hline 43 & $\begin{array}{l}\text { The accounting information system restricts to authorized personnel the ability to create, change, or delete leases or } \\
\text { receivables. }\end{array}$ \\
\hline 44 & $\begin{array}{l}\text { The accounting information system defines tolerance levels for allowable cash discounts and cash payment } \\
\text { differences; amounts in excess of such levels are not allowed to be entered into the information system. }\end{array}$ \\
\hline 45 & $\begin{array}{l}\text { The accounting information system reports gaps in document numbering which are reviewed regularly by } \\
\text { management. }\end{array}$ \\
\hline 46 & ancial documents in real time. \\
\hline
\end{tabular}




\section{CONCLUSION}

The current paper provides an internal control checklist for income producing real estate revenue that, when used as a benchmark, will aid managers and independent auditors in assessing a firm's control policies and procedures. Specifically, the checklist will be useful in preliminarily assessing whether the appropriate revenuerelated internal controls are in operation. In light of today's competitive global economic environment and the increasing importance of revenue-related internal controls, the checklist is both important and timely. In addition to use by professionals, the checklist can be used in the classroom to highlight the importance of revenue-related internal controls.

\section{ACKNOWLEDGEMENTS}

The authors wish to thank the management of a large anonymous CPA firm for allowing access to data which were useful in the preparation of this paper.

\section{AUTHOR INFORMATION}

Tim Kizirian, Ph.D., CPA, is a Professor at California State University, Chico. He received his MBA from Cal Poly, San Luis Obispo and his M.A. and Ph.D. from the University of Arizona. He can be reached at E-mail: tkizirian@csuchico.edu

Tim Heinze, Ph.D., is an Assistant Professor at California State University, Chico. He received his MS from Texas A\&M University and his Ph.D. from Capella University. He has worked for a Detroit Three automotive firm. He can be reached at E-mail: tcheinze@ csuchico.edu (Corresponding author)

Wallace Leese, Ph.D., CMA, is a Professor at California State University, Chico. He received his BBA from Niagara University, and his MSA and Ph.D. from Arizona State University. He can be reached at E-mail: wleese@csuchico.edu

Samir Nissan, Ph.D, MBA, is a Professor Emeritus of accounting at California State University, Chico. He received his MBA from the University of Southern California, and a Ph.D. from the University of Illinois, UrbanaChampaign. He can be reached at E-mail: snissan@csuchico.edu

Paule Pobloske, MBA, CPA, is a Lecturer at California State University, Chico. She received her MBA from Chicago University in 2001. She can be reached at (773) 895-1768 or at E-mail: ppobloske@ csuchico.edu

\section{REFERENCES}

1. American Institute of Certified Public Accountants (AICPA). (2002). Consideration of Fraud in a Financial Statement Audit. Statement on Auditing Standards No. 99. New York, NY: AICPA.

2. Kizirian, T., Heinze, T., \& Lees, J. (2011). Internal controls for hospitality revenue in the gaming industry. Journal of Business \& Economics Research, 9(8), 15-18.

3. Moodys/REAL Commercial Property Price Index (CPPI) at http://web.mit.edu/cre/research/credl/rca.html. Accessed July 25, 2011.

4. Public Company Accounting Oversight Board (PCAOB). (2007). An Audit of Internal Control Over Financial Reporting That Is Integrated with An Audit of Financial Statements. Auditing Standard No. 5 